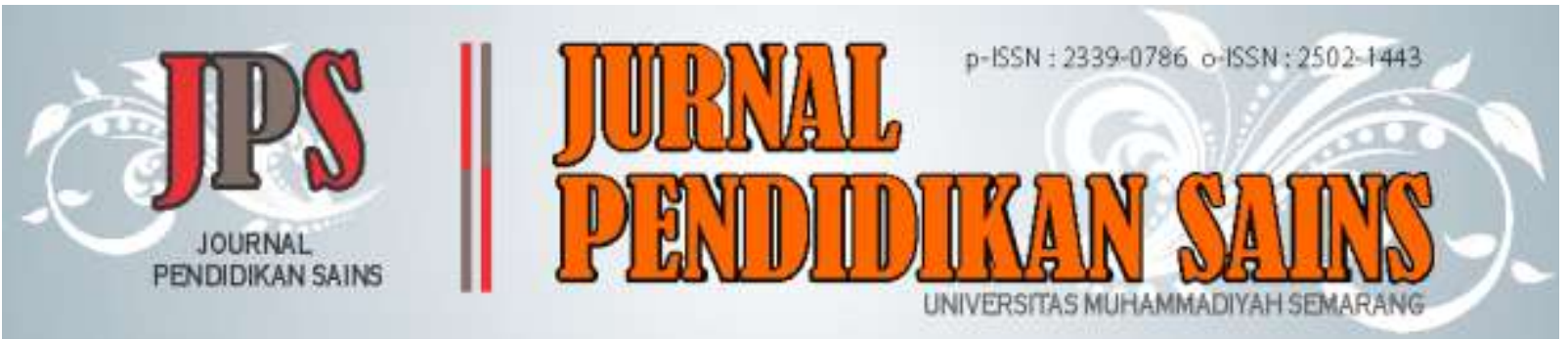

\title{
Development of Acid-Base Online Science Literacy Test Instruments
}

\author{
Anita Fadhilah $^{\text {a,1,*}}$, Sri Haryani ${ }^{\text {b,2 }}$ \\ ${ }^{a}$ Pendidikan Kimia, Universitas Negeri Semarang, Semarang (50229), Indonesia \\ ${ }^{\mathrm{b}}$ Pendidikan Kimia, Universitas Negeri Semarang, Semarang (50229), Indonesia \\ ${ }^{1}$ afadhilah9@gmail.com*; ${ }^{2}$ haryanimail@gmail.com \\ * corresponding author
}

\begin{tabular}{ll}
\hline \multicolumn{2}{l}{ Article history } \\
\hline Submission & $: 2021-05-06$ \\
Revised & $: 2021-08-10$ \\
Accepted & $: 2021-10-17$
\end{tabular}

\begin{abstract}
Facing the 21st century, students need to have basic knowledge of science. Scientific literacy relates to how students conceive the environment, health, economy, and problems of modern society, which are more concerned with technology, advancement, and science development. Therefore, it is necessary to develop a scientific literacy test instrument to measure students' scientific literacy skills. The objectives of this study were (1) to examine the (2) analyze the level of validity and reliability of online scientific literacy test instruments in acid-based material, and (3) examine the profile of students' scientific literacy skills toward the test instrument. This Research and Development (R\&D) 4D model, which was adapted by Thiagarajan (1974), shows the feasibility and validity of the scientific literacy test instrument with scores of 0.414 and 0.782 , respectively. The profile of students' scientific literacy skills was in good criteria of $67 \%$. The students' scientific literacy skills of competence aspects were $66 \%, 63 \%$, and $72 \%$, respectively.
\end{abstract}

Keyword

Scientific Literacy

Test Instrument

Acid-Base

This work is licensed under a Creative Commons Attribution 4.0 International

License

\section{INTRODUCTION}

The rapid development of science and technology in the 21 st century requires students not to continue to think conventionally (Rahayu, 2019). Another challenge in facing the 21st century is the importance of students having a foundation in science (Suma et al., 2018). The ability of scientific literacy relates importantly to how they conceive the environment, health, economy, and the problems of modern society, which are more concerned with technology, progress, and science development (Rusilowati et al., 2016).

The scientific literacy ability of Indonesian students based on PISA and TIMMS shows that they are still in the lower stage. Indonesia's ranking In 2018 for science, reading, and mathematics was ranked 71, 74, and 73 out of a total of 79 PISA members (OECD, 2019). Indonesian students' low scientific literacy skills are caused by various factors, including education, which is still oriented to tests and exams (Gherardini, 2016). Teacher learning still emphasizes concepts, laws, and theories (Ardiyansyah et al., 2016). Based on the Republic of Indonesia, Joko Widodo, education in Indonesia is expected to increase, especially in literacy, mathematics, and science skills. No more Indonesian students would be left behind (Widodo, 2020).

The observations in four high schools in Semarang show that some teachers still have not used scientific literacy-based test instruments. Research conducted by Dwi (2019) revealed that some teachers generally had not developed test instruments based on scientific literacy. The instrument used by teachers 
to measure student learning outcomes still uses common questions that only measure aspects of knowledge and emphasize measuring conceptual understanding (Prabowo \& Fidiastuti, 2017).

Chemical materials are conceptual and applicable, so they are close to daily life (Yohana et al., 2018). Chemistry in science learning expects students to have skills and apply them to daily life (Rosidah, 2017). Chemical materials that are suitable for development in scientific literacy instruments are acidbase materials. Acid-base is a material that must be mastered by students (Amry et al., 2017). This material is required to proceed to the following material, namely Hydrolysis, Buffer, and Ksp, so it is necessary to understand the correct and complete concept. According to Islami (2016), acid-base material includes the basic principles of content selection according to PISA, namely: (1) content must be relevant to daily life. The concept of acid-base can be found in daily life, such as food products and beverages. (2) acid-base material will remain relevant for many years to come, and (3) the content applied must be related to the competence/process and not only rely on students' memory.

This research aimed to measure students' scientific literacy skills. The aspects of content were competence/process and scientific context an-based scientific literacy test instruments online on acid-base material. The test instrument is based online on Google Form. It is more practical in assessment, reciprocal speed, more personal, and environmentally friendly (Jeong, 2014). In addition, the test instrument is online and expected to measure scientific literacy skills by utilizing the digital world for the millennial generation in Indonesia.

\section{METHOD}

This Research and Development were designed to produce an-based scientific literacy test instrument online for high school students on acid-base material that adapted the Thiagarajan model (1974). This Research model Four D has four stages, including define, design, development, and dissemination. The research subjects are grade XI students majoring in Mathematics and Natural Sciences academic year 2020/2021. There are two tests in the study. The small-scale test respondents were 36 students, and the large-scale test with respondents was 65 students. Small-scale tests were carried out to determine the readability and feasibility of test instruments. Large-scale tests were used to determine the profile of students' scientific literacy abilities.

This research's data collection techniques consisted of scientific literacy test instruments, response scales, interviews, expert validation, and documentation studies. The research data were analyzed qualitatively and quantitatively. The validity of the questions is calculated by calculating the value of the biserial coefficient, and its reliability is determined using the KR-20.

\section{RESULTS AND DISCUSSION}

\section{Results}

The define stage obtained the results from observations and literature reviews. In the observation stage, which was supported by preliminary interviews, it was known that many teachers did not understand scientific literacy, and the assessment instruments used still did not fulfill the aspects of scientific literacy. The literature review stages obtained results in the importance of students having scientific literacy skills (Rusilowati et al., 2016). Science literate students are expected to be able to use scientific information in overcoming problems in daily life.

The design stage obtained results in the form of test instruments and non-test instruments. The test instrument developed in the study was 30 multiple-choice items that cover aspects of scientific literacy. The design stage is also carried out by expert validation. The results of expert validation are used as a reference for revising the test instrument before the test is carried out.

The development stage consists of two tests, namely the small-scale test and the largescale test. Small scale test obtained an average validity of 0.32 with 24 valid questions from 30 questions. The results of the validity of the large-scale test obtained an average validity of 0,41 , with 29 questions declared valid from a total of 30 questions. The reliability of the scientific literacy test instrument on the small scale test was 0,733 , and the large scale test was 0,782 .

The dissemination stage obtained the final product in the form of a test instrument and an article output disseminated through journal publications. The final product in the form of test 
instruments and articles is expected to be used as a reference for readers in using or developing scientific literacy test instruments on acid-base or other materials.

\section{Discussion}

\section{Feasibility of Scientific Literacy Test Instruments}

The feasibility of scientific literacy test instruments online on acid-base material developed refers to expert validation and supporting data in teacher and student response scales. The results of expert validation on the developed test instruments showed valid results. In developing the test instrument, several questions must be revised according to the advice of the experts. The following is an example of a revised item after validation by an expert:

5. Aluminum and Iron are easily damaged when reacted with acidic solutions. The stronger the acid, the more efficiently the metal is damaged, so it is not surprising that motorized vehicles are relatively easily damaged and corroded in areas where acid rain often occurs. This can result in a decrease in the quality of the motorized vehicle. It is easy for metals to be damaged by acidic solutions due to acidic solutions.

a. easy to neutralize

b. corrosive

c. redden blue litmus paper

d. bluish red litmus paper

e. indicates a $\mathrm{pH}$ less than 7

Question number 5 contains indicators to identify substances that are acidic or alkaline in daily life. The indicators of scientific literacy in the question are acid content in daily life, with the competence to interpret data and evidence scientifically, and the context in the form of threats or dangers. This problem underwent a revision in the sentence structure where the question still had to improve, so unnecessary information did not need to be included. Then, there is no need to include aluminum because aluminum is a metal that is not prone to corrosion, so just iron is enough. Because this can lead to misconceptions in students. After revisions were made based on expert opinion, question number 5 was corrected as follows:

5. Iron is easily damaged when reacted with acidic solutions. The stronger the acid, the more quickly the metal is damaged. Therefore, in areas where rain often occurs, motorized vehicles are relatively prone to damage and rust. It is easy for iron metals to be damaged by acidic solutions due to acidic solutions.

a. easy to neutralize

b.corrosive

c.redden blue litmus paper

d.bluish red litmus paper

e.indicates a $\mathrm{pH}$ less than 7

\section{Read the text below!}

A student experiments by observing the rain. Natural rain is known to have reasonably acidic properties, with a $\mathrm{pH}$ of 5.6. Carbon dioxide combines with water in the atmosphere to form carbonic acid, a weak acid that dissociates to produce hydronium and bicarbonate ions.

$\mathrm{CO}_{2}(\mathrm{~g})+\mathrm{H}_{2} \mathrm{O}(\mathrm{l}) \rightleftharpoons \mathrm{H}_{2} \mathrm{CO}_{3}(\mathrm{aq})$

$\mathrm{H}_{2} \mathrm{CO}_{3}(\mathrm{aq})+\mathrm{H}_{2} \mathrm{O}(\mathrm{l}) \rightleftharpoons \mathrm{H}_{3} \mathrm{O}^{+}(\mathrm{aq})+\mathrm{HCO}_{3}^{-}(\mathrm{aq})$

13. The concept of acid-base according to who is present in the weak acid dissociation reaction in the rain above
a. Lewis
b. Arrhenius
c. Bronsted Lowry
d. Lux Flood
e. Lowry

Question number 13 contains indicators of explaining various acid-base concepts. The indicators of scientific literacy in the question are the content of acid-base theory with the competence to identify and design scientific investigations and the environmental context. The question has been revised in several parts, the sentence structure needs to be improved, so it is easy for students to understand, and the arrangement of answer choices is made in 
alphabetical order. After a revision was made based on the opinion of the expert, question number 13 can be seen as follows:

\section{Read the text below!}

A student experiments by observing the rain. It is known that natural rain has quite acidic properties, with a $\mathrm{pH}$ of 5.6. Carbon dioxide combines with water in the atmosphere to form carbonic acid, a weak acid that dissociates to produce hydronium and bicarbonate ions. $\mathrm{CO}_{2}(\mathrm{~g})+\mathrm{H} 2 \mathrm{O}(\mathrm{l}) \rightleftharpoons \mathrm{H}_{2} \mathrm{CO}_{3}(\mathrm{aq})$

$\mathrm{H}_{2} \mathrm{CO}_{3}(\mathrm{aq})+\mathrm{H}_{2} \mathrm{O}(\mathrm{l}) \rightleftharpoons \mathrm{H}_{3} \mathrm{O}^{+}(\mathrm{aq})+\mathrm{HCO}_{3}{ }^{-}(\mathrm{aq})$

13. The concept of acid-base according to who is present in the weak acid dissociation reaction in the rain above.
a. Arrhenius
b. Bronsted Lowry
c. Lewis
d. Lowry
e. Lux Flood

The feasibility of the test instrument is also seen from the scale of teacher and student responses. The results of the scale of the teacher's responses to the test instrument stated that they were feasible to use. The score for the teacher response scale was obtained by 37 from a total score of 40, which means that the test instrument was excellent and feasible to use. Based on the teacher response scale, the developed test instrument was good with $92.5 \%$. The student response scale was estimated using the Cronbach Alpha formula, and the reliability was obtained at 0.86. From the scale analysis, the student's responses to the test instrument were stated to be good, with a percentage of $82.02 \%$.

Validity and Reliability of Test Instrument

The calculation of the validity of the items was carried out in small and large-scale tests. Analysis of the validity of the small and large scale tests was carried out using Microsoft Excel 2016 program. In the small-scale test, six questions were invalid, with a validity of less than 0.3 . The invalid questions are questions number 6, 8, 10, 14 and 16, and 29. Validity results of the small-scale test were used as evaluation material to make revisions to the questions that were not valid yet. The test instrument was tested on a large-scale test. The questions on the large-scale test were declared valid with an average validity coefficient of 0.413 .

Several factors affect the validity of the questions according to research conducted by Rusilowati (2016), including (1) the ability of students; (2) The teacher's objectivity in the assessment (3) the conditions of the education participants. This factor is in line with the validity factor, according to Yusup (2018). The condition of students greatly affects the results of working on the test instrument, which in turn can affect the validity value of the test instrument. There were still invalid questions in the large-scale test, that was point number 29, with a validity of 0.153 . Furthermore, revisions were made with questions that had indicators of competency achievement and indicators of scientific literacy that were the same in the parts of the questions that were still not valid. It is intended that a suitable instrument be obtained as the final product of this research.

Before calculating the reliability of the questions, the difficulty index was calculated for each question. The results of the proportion of the difficulty index on a large-scale test were effortless, easy, medium, and complex. The proportion of the difficulty index of large-scale test items can be seen in Figure 3.1. 


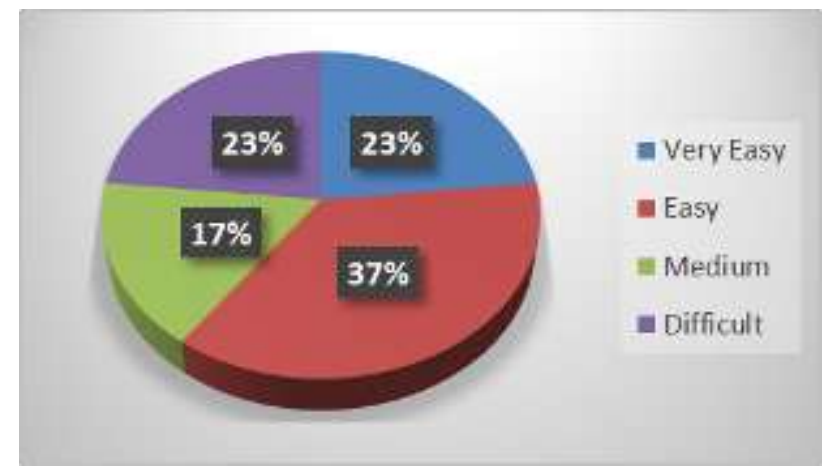

Figure 3.1 Proportion of Difficulty Index

The test instrument in small scale was declared reliable, with a reliability coefficient of 0.733 . At the same time, the insignificant scale test obtained a reliability coefficient of 0.782 . The test instrument is declared reliable and can be used to measure scientific literacy skills. A reliable test instrument is needed in learning to correctly measure skills and abilities (Putri et al., 2020).

The factors that cause differences in the reliability of small and large-scale tests include the readiness of students to work on questions. This reliability factor is also in line with BSNP (2010). the consistency of an instrument is influenced by a large number of items, the condition of students, the distance from the first test to the second test, any disturbances or obstacles experienced in implementing the test, and each student's readiness. The reliability analysis results of the test instruments described above, the the-based scientific literacy test instrument online on acid-base material, are declared reliable.

Profile of Students' Scientific Literacy Skills

Analysis of the test results of acid-base scientific literacy test instruments on a large-scale test obtained a percentage of the scientific literacy ability profile of $67 \%$. At $65 \%<\mathrm{P} \leq 79 \%$, students' scientific literacy skills are in good criteria. This good literacy category is because students have started to get used to scientific literacy test instruments, especially on acid-base material. The profile of students' scientific literacy can be seen in Figure 3.2.

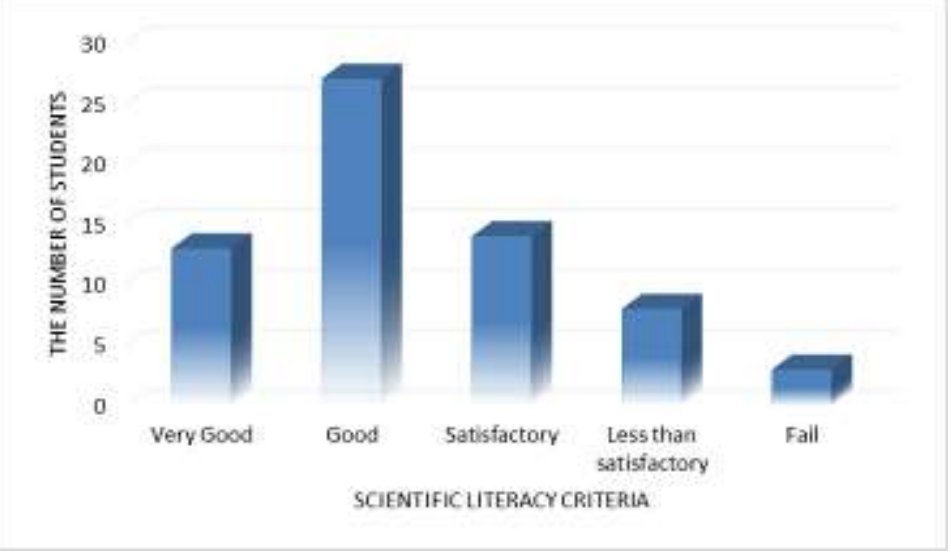

Figure 3.2 Profile of Students' Scientific Literacy Skills

Most students are in good criteria, and there are 27 students. In this category, students are considered capable and are getting used to understanding and completing scientific literacy test instruments. Meanwhile, students were at least in the failing criteria, and there were three students. Students in the failing category have not been able to link learning with scientific phenomena/issues in daily life and are not yet familiar with scientific literacy test instruments. Several factors that affect students' scientific literacy skills, according to the OECD (2017), include environmental, gender, social, and economic factors. 
The percentage results of the scientific literacy profile based on the test instrument are also in line with the scientific literacy competency analysis results. There are three components of scientific competencies or processes that have been determined by PISA in the scientific assessment, including explaining issues/phenomena scientifically, identifying and designing scientific investigations, and interpreting scientific data and evidence. The percentages of each category were $66 \%, 63 \%$, and $72 \%$ at a percentage of $55 \%<\mathrm{P} 65 \%$ of students 'scientific literacy skills were in the sufficient criteria, while at $65 \%<\mathrm{P} 79 \%$ of students' scientific literacy abilities were in good criteria. The percentage of students' scientific literacy skills can be seen in Figure 3.4 .

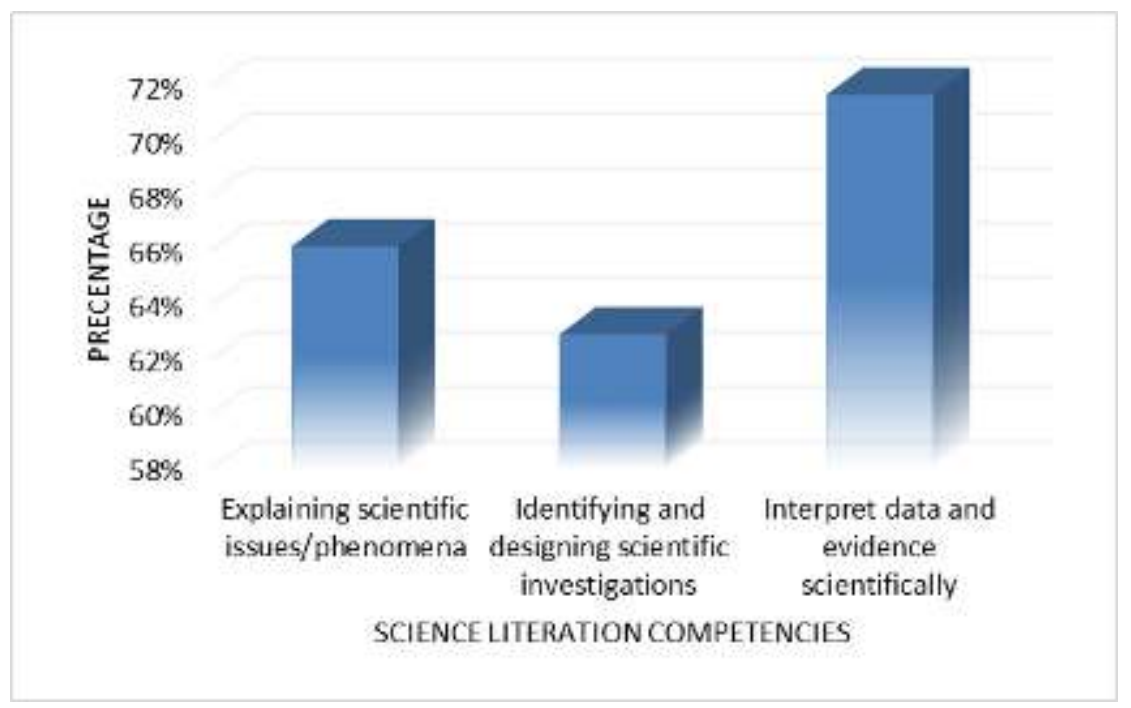

Figure 3.3 Percentage of Students' Science Literacy Ability

The highest percentage results were obtained in the competence to interpret data and evidence scientifically, $72 \%$. Students can interpret data and evidence scientifically in working on scientific literacy test instruments on acid-base material.

The percentage of scientific literacy competence in explaining scientific issues/phenomena was $66 \%$ or suitable. Students can understand scientific issues and phenomena given to the test instrument. The student's

understanding can be proven by the ability of students to use their scientific knowledge to solve scientific literacy problems based on the concept of acid-base. Factors that affect the ability of students to solve problems explain scientific issues and phenomena, namely the concept of knowledge that students have (Wulandari \& Sholihin, 2016).

The competence in identifying and designing scientific investigations is in the moderate category with $63 \%$. Students are sufficiently able to answer questions on the test instrument to identify and design scientific investigations. The ability of students to identify and design scientific investigations is closely related to their scientific knowledge of the concept of acidbase. Questions on the test instrument connect many cognitive aspects of students with general phenomena in life. The competence in identifying and designing scientific investigations is also influenced by the learning process passed. The learning process lacks in implementing practicum or projects so that students are not used to identifying or designing scientific investigations. In line with research on the development of test instruments by Sukowati (2017), students are still not familiar with problems based on scientific literacy.

The low competence of identifying and designing scientific investigations can also be caused by students still having difficulty understanding and applying scientific concepts to solve the problems of everyday life (Nurwahidah, 2019). The difficulties align with Wijaya's research (2017), where the learning process is still unrelated to everyday problems. Students are still lacking in solving problems related to their daily lives, and students lack the understanding to 
appreciate the benefits of chemistry. According to Haryani (2017), students need to be accustomed to applying skills in dealing with problems related to daily life.

According to Lyle (2001), students use more of their initial knowledge and are associated with new knowledge obtained by the cognitive learning theory. In line with research conducted by Wulandari (2016), the level of cognitive aspects of students will affect the ability of students to recognize scientific issues or phenomena. The greater the cognitive aspects contained in students' memory, the greater the ability of students to solve scientific literacy questions. The cognitive is because students can analyze scientific issues or phenomena in the questions and connect them with their knowledge.

Cognitive processes involved in scientific competence include inductive/deductive reasoning, critical and integrated thinking, changing representations, constructing explanations based on data, thinking using models, and using mathematics (OECD, 2018). The "adequate" and "good" categories in scientific literacy competencies indicate that students' abilities are not optimal in mastering scientific literacy abilities. Mastery of students' scientific literacy abilities is influenced by many factors, including the science learning methods used by teachers in determining learning concepts.

The results of the question analysis are in line with the results of interviews of students regarding scientific literacy skills. Interviews were conducted via google meet and WhatsApp video call with nine students as respondents of the upper, medium, and low classes. The students' responses to the acid-base scientific literacy test instrument were different. Most of the students stated that the scientific literacy test instrument questions were different from the usual test questions given by the teacher. Students in the high and medium category said the differences in the scientific literacy test instrument emphasized more logic and connected more questions to events in everyday life. Students expressed that they were challenged to answer questions in the low category because they were still not used to connecting scientific phenomena that existed in everyday life with questions.

\section{CONCLUSION}

The scientific literacy test instrument was declared feasible based on expert validation and supporting data on the scale of the responses of teachers and students. Based on the teacher response scale, the developed test instrument was good with $92.5 \%$. The student response scale was estimated using the Cronbach Alpha formula, and the reliability was obtained at 0.86 . From the scale analysis, the student's responses to the test instrument were stated to be good, with a percentage of $82.02 \%$. The profile of students' scientific literacy abilities is based on scientific competencies. The PISA has set for the competence to explain scientific issues/phenomena is $66 \%$ in the excellent category, identifying and designing scientific investigations is $63 \%$ in the good category, and the competence to interpret data and evidence scientifically is $72 \%$ in the excellent category.

\section{SUGGESTION}

(1) The scientific literacy test instrument applied in chemistry learning should also be followed by teaching and learning materials that apply scientific literacy in order to be able to improve students' scientific literacy skills.

(2) The results showed that the scientific literacy ability of the test instruments developed was in a good category, but it needed to be improved with other scientific literacy instruments.

(3) The results of the scientific literacy profile of scientific competence show that the category of identifying and designing scientific investigations is in a good category. It is hoped that it will be improved again in the future, especially in the scientific literacy competence, so that students' scientific literacy skills can be better.

(4) To further develop the test instrument, it is intended to link the items with the level of scientific literacy.

\section{ACKNOWLEDGMENT}

https://jurnal.unimus.ac.id/index.php/JPKIMIA/index 
Thanks to the supervisor who has contributed so that this research can be carried out.

\section{REFERENCES}

Ardiyansyah, A. A. I., Irwandi, D. \& Murniati, D. (2016). Analisis Literasi Sains Siswa Kelas XI IPA pada Materi Hukum Dasar Kimia di Jakarta Selatan. Educhemia, 1(2), 149-161.

Amry, U. W., Rahayu, S. \& Yahmin. (2017). Analisis Miskonsepsi Asam Basa pada Pembelajaran Konvensional dan Dual Situated Learning Model (DSLM). Jurnal Pendidikan , 2(3), 385-391.

BSNP. (2010). Paradigma Pendidikan Nasional Abad XXI. [Online]. Tersedia: http://www.bsnpindonesia.org/id/wp-content/uploads/2012/04/LaporanBSNP-2010.pdf diakses pada tanggal 18 September 2020.

Depdiknas. (2016). Panduan Penulisan Soal 2016. Jakarta: Pusat Penilaian Pendidikan Badan Penelitian dan Pengembangan Kementerian Pendidikan dan Kebudayaan.

El Islami, R. A. Z., Nahadi, N., \& Permanasari, A. (2016). Membangun Literasi Sains Siswa pada Konsep Asam Basa melalui Pembelajaran Inkuiri Terbimbing. Jurnal Penelitian dan Pembelajaran IPA, 2(2), 110-120.

Gherardini, M. (2016). Pengaruh Metode Pembelajaran dan Kemampuan Berpikir Kritis Terhadap Kemampuan Literasi Sdwiains. Jurnal Pendidikan Dasar, 7(2), 253-264.

Haryani, S., Prasetya, A. T., \& Bahron, H. (2017). Building the character of pre-service teachers through the learning model of problem-based analytical chemistry lab work. Jurnal Pendidikan IPA Indonesia, 6(2), 229-236

Jeong, Hanho. (2014). A Comparative Study of Scores on Computer-based Tests and Paperbased Test. Behaviour \& Information Technology, 33(4), 410-422.

Nurwahidah, I., Widiyawati, Y., \& Sari, D. S. (2019). Pengembangan Integrated Science Assesment Berbasis PISA untuk Peserta Didik Kelas VII SMP. Jurnal Pendidikan Sains (JPS), 7(2), 147-156.

OECD (2018). PISA 2015 Result in Focus. Paris: OECD Publishing.

OECD. (2017). PISA 2015 Assessment and Analytical Framework: Science, Reading, Mathematics, Financial Literacy, and Collaborative Problem Solving. Revised Edition ed. Paris: OECD Publishing.

OECD, (2019). PISA 2018 Result Combined Execute Summaries Volume I, II, \& III. Paris: OECD.

Prabowo, C. A. \& Fidiastuti, H. R. (2017). Measuring First Year Student Scientific Literacy Skills using Test of Scientific Literacy Skills (TOSLS). Bioeducation Journal, 1(2), 78-85.

Putri, R., Sari, R., Jumadi \& Ariswan. (2020). Pengembangan dan Validasi Instrumen Tes untuk Mengukur Keterampilan Menyelesaikan Masalah Peserta Didik SMA pada Pelajaran Fisika. Jurnal Penelitian Pembelajaran Fisika, 11(1), 17-25.

Rahayu, V. A., Haryani, S., \& Dewi, S. H. (2019). Keefektifan Pengembangan Instrumen Tes untuk Mengukur Kemampuan Berpikir Kreatif Siswa. Chemistry in Education, 8(2), 51-55.

Rosidah, T., Astuti, A. P., \& Wulandari, V. A. (2017). Eksplorasi Keterampilan Generik Sains Siswa Pada Mata Pelajaran Kimia di Sma Negeri 9 Semarang. Jurnal Pendidikan Sains (JPS), 5(2), 130-137.

Rusilowati, A., Kurniawati, L., Nugroho, S. E. \& Widiyatmoko, A. (2016). Developing an Instrument of Scientific Literacy Assessment on the Cycle Theme. International Journal of Environmental \& Science Education, 11(12), 5718-5727.

Septiani, D., Widiyawati, Y., \& Nurwahidah, I. (2019). Pengembangan Instrumen Tes Literasi Sains Berbasis PISA pada Aspek Menjelaskan Fenomena Ilmiah untuk Siswa Kelas VII. Science Education and Application Journal, 1(2), 46-55.

Sudaryono, Margono, G. \& Rahayu, W. (2013). Pengembangan Instrumen Penelitian Pendidikan. Yogyakarta: Graha Ilmu. 
Sukowati, D., Rusilowati, A. \& Sugianto. (2017). Analisis kemampuan literasi sains dan metakogntif peserta didik. Physics Communication, 1(1), 16-22.

Suma, K., Sadia, I. W. \& Pujani, M. N. (2018). Investigating 12th-Grade Students' Prior Knowledge of Static Electricity Concepts. International Journal of Environmental \& Science Education, 13(2), 163-172.

Widodo, J. (2020). Rapat Terbatas Strategi Peningkatan Peringkat Indonesia dalam PISA, Jakarta: Sekretariat Presiden.

Wijaya, U. R. B., Sumarni, W., \& Haryani, S. (2017). Pengembangan Instrumen Penilaian Berpikir Kritis pada Pembelajaran Kimia Berpendekatan Sets (Science, Environment, Technology, and Society). Chemistry in Education, 6(2), 35-41.

Wulandari, N., \& Sholihin, H. (2016). Analisis Kemampuan Literasi Sains pada Aspek Pengetahuan dan Kompetensi Sains Siswa pada Materi Kalor. EDUSAINS, 8(1), 66-73.

Yohana, I., Sudarmin, S., Wardani, S. \& Norasikin, S. (2018). The Generic Science Skill Profile of Fourth Grade Students on Acid and Base Topic in Guided Inquiry Learning Model. International Journal of Active Learning, 3(2), 110-116.

Yusup, F. (2018). Uji Validitas dan Reliabilitas Instrumen Penelitian Kuantitatif. Jurnal Tarbiyah, 7(1), 17-23. 